- Earthquake Effects

- Earthquakes as Natural Disasters.

- Earthquake-Resistant Design and Construction and Hazard Reduction.

Subscription Rates - Effective August 1, 1974

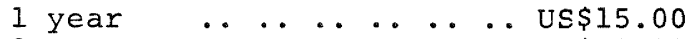

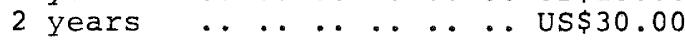

For airmail delivery ..... US $\$ 3.00 / y r$.

Mail orders to :-

Abstract Journal in Earthquake Engineering,

Earthquake Engineering Research Center, University of California,

1301 Scuth 46 th Street.

Richmond, California, U.S.A. 94804.

\section{SOUTH PACIFIC REGIONAL CONFERENCE ON EARTHQUAKE ENGINEERING 13-15 MAY, 1975}

A Report by R. W. G. Blakeley.

"... To strive, to seek, to find, and not to yield."

With those words of A. L. Tennyson, Mr. D. S. Mackenzie, President of the New Zealand National Society for Earthquake Engineering, closed the South Facific Regional Conference on Earthquake Engineering. Although modern earthquake engineering is not so uncompromisingly insistent on exclusively elastic structural behavicur, the same quest for knowledge that inspired Ulysses pervaded the conference. Those who attended, left aware both of exciting advances in the science and art of earthquake engineering and of the continuing need for more information on the phenomena of earthquakes and their effects on engineering structures.

\section{Conference setting}

The conference attendance numbered 160 including delegates from Australia, Japan, Papua and the U.S.A. Keynote addresses were delivered by specially invited guests; Karl V. Steinbrugge, Professor of Structural Design, University of California, U.S.A., and Vitelmo V. Bertero, Professor of Civil Engineering, University of California, Berkeley, U.S.A. Another prominent conference member was Dr. Kiyoshi Muto, Fresident, Muto Institute of Structural Mechanics, Tokyo, Japan and a past-president of the International Association for Earthquake Engineering. The conference is a quadrenniel event under the auspices of the New Zealand National Society for Earthquake Engineering and the organiser on this occasion was Mr. G. H. F. McKenzie. The venue was Victoria University of Wellington.

Hon. M. Connelly, Minister in Charge of the Earthquake and War Damage Commission, opened the conference and in his remarks emphasised the risk taken by those 15 percent of all home and business owners in New Zealand who chose not to insure themselves against fire and therefore are not covered for earthquake damage. Mr. Connelly said that after the Richter magnitude 7.0 Inangahua earthquake in May 1968 the Commission received 10,500 damage claims which when settled were worth $\$ 2,400,000$. This earthquake struck a lightly populated region and it is a matter for conjecture what the figures would be if there was a similar earthquake in a large city such as Wellington. $\mathrm{Mr}$. Connelly encouraged conference members in their responsibilities of ensuring that earthquakes would cause minimum loss of life and minimum economic loss to properties.

\section{Keynote Addresses}

The keynote addresses were highlights of the conference. Professor steinbrugge spoke on earthquake disaster response planning from the viewpoint of one who has had considerable experience in the fomulation of public policy related to earthquake hazard reduction in the U.S.A. The problem is generally approached from three aspects: ife safety, property damage, and functional impairment. Life safety is the highest priority and present American building codes concentrate on this rather than damage control. However, the cost of reconstruction after recent earthquake disasters has prompted concern for property damage. Functional impairment is serious where egress from buildings is inhibited by falling debris or where vital public utilities such as hospitals become nonfunctional after the earthquake due to failure of support systems.

Professor Steinbrugge outlined several concepts behind methodologies to determine the potential aggregate damage for selected postulated earthquakes in the metropolitan Les Angeles and metropolitan San Francisco Bay areas. These required estimates of the potential losses to medical resources and the likely demands on such resources for treatment of human casualties following vibrational damage to buildings and dams. As vell as planning for such after-the-event efforts, there is clearly need for planning for pre-earthquake hazard reduction such as the strengthening or razing of hazardous structures or parts of structures. Finally, Professor Steinbrugge spoke on insurance aspects of the monetary loss from a large disaster.

Professor Bertero outlined problem areas that exist in the earthquake resistant design of building structures and discussed current research efforts to obtain the necessary information to resolve them. Specific areas mentioned were: establishment of likely critical ground shaking at a building site as a basis for design; allowance for the non-deterministic nature of the mechanical characteristics of materials and the need for integrated experimental and analytical studies of the earthquake resistance of new structural systems; prediction of the mechanical behaviour of structures, intrinsic to any design method entailing modelling of the structure, structural analysis, and proportioning and detailing of members and their supports and connections; and finally because the nature of earthquake resistant design is nondeterministic, the need for the designed structure to be subject to analyses to check its reliability under the bounds of possible ground shaking and mechanical behaviour of the soil-structure system. The importance of construction aspects such 
as quality control of materials, workmanship and inspection were also noted. Professor Bertero emphasised the need for co-ordination of national and international research efforts and the translation of the ensueing results into information useful to design engineers and code writers.

\section{Conference Papers}

One of the most important recent developments in New zealand reported to the conference was the compilation of the new code loading earthquake provisions. The draft in virtually final form was circulated for conference members and discussed by $\mathrm{Mr}$. D. Kolston on behalf of the seismic loads sub-committee of SANZ. The new code introduces the concept of multi-term evaluation of the horizontal seismic design coefficient to be applied to various structures. One of these terms relates to the importance of structures and the degree to which they are required to be functional following earthquakes. Another requires increased loading for structures which dissipate energy in a manner other than by ductile flexural yielding. Also, quantitative provisions are now made for flexible soils. Another new provision is the requirement that buildings designed for flexural ductile yielding (or for yielding in diagonal braces with some limitations) are to be the subject of capacity design. This requirement includes consideration of concurrent yielding response in both principal axes of a structure under earthquake attack inclined to these axes. More stringent non-structural damage control measures are also introduced. The provisions are to be considered in more detail in forthcoming regional seminars and it is hoped that all disciplines affected will contribute to general discussion of the code.

Another important development with attractive potential is the use of base isolation systems to increase the earthquake resistance of buildings. Mr. R. I. Skinner reported on development of energy dissipating devices at the N.Z. Department of scientific and Industrial Research. These devices utilize the plastic deformation of solid steel bars and when combined with a foundation system allowing base flexibility they can isolate the structure from the major effects of earthquake attack. Seismic response analyses of single-mass linear and bilinear hysteretic resonators with base isolation showed the principal advantages to be for short period structures, less than approximately 0.7 seconds. Within this range base isolation suppresses the ductility demand on the structure with corresponding advantages such as non-structural damage protection.

The 24 papers presented at the conference covered a wide range of current earthquake engineering activitiy. Papers dealing with ground response included studies in Papua and the Hutt Valley. Factors which must be taken into account in earthquake risk analyses, such as variations in tectonic setting, in soil conditions, and in recently elucidated source properties of earthquakes themselves, were discussed with reference to New Zealand conditions which may vary significantly from other countries on the circumPacific belt. One presentation entailed the estimation of earthquake induced soil pressures on a wall forming part of the structure of a power station founded on rock. Other papers dealt with one of the following three facets of building design: structural analysis, design principles, and element detailing. These included the results of a number of inelastic dynamic analyses of multistorey structural steel and reinforced concrete frame and cantilever shear wall buildings. Capacity design principles for reinforced concrete frames were enunciated and the actual design of a 28-storey reinforced concrete building described.

\section{Adequate detailing of beam-column} joints in framed structures has exercised the minds of many designers and researchers and results were presented from testing of prestressed concrete, reinforced concrete, and structural steel beam-column joint units. Other papers on the seismic performance of elements dealt with brick masonry walls and masonry infill panels. Attention was drawn to the need for separation of non-structural components in buildings, both to minimise non-structural damage, which might otherwise represent the greatest monetary loss in modern buildings, and to reduce the hazard to people should nonstructural elements fail. A listing of all papers presented at the conference is included at the end of this report. All papers have been or will be published in the Bulletin of the New Zealand National Society for Earthquake Engineering.

Five films were shown during the course of the conference. Dr. Muto showed films on the testing of seismic resistant slit walls developed by Kajima Corporation and on the design and construction of a 20-storey reinforced concrete framed building in Japan. Differences were evident between current Japanese and New Zealand practice. A film was shown of dynamic testing at University of California, Berkeley, of a model of a curved multiple-span reinforced concrete bridge which collapsed during the San Fernando, 1971, earthquake. The damage caused to the expansion joints by impacting in both torsional and translational modes was graphically illustrated. Research at University of Canterbury, under Professor R. Park's supervision, on shaking table tests of a 6-storey $\frac{3}{4}$-scale model reinforced concrete frame was shown. This film highlighted the torsion induced by flexing of the floor slab in beams transverse to the principal direction of sway, a recurrent concern expressed during the conference. Professor Bertero also showed film of dynamic structural testing at Berkeley.

\section{Social}

One of the undoubted benefits to be derived from such a conference is the social contacts made between formal sessions. The social highlight was the conference dinner. Members and their wives were entertained by Professor John I. Roberts, Professor of Public Administration, Victoria University of Wellington, with an appropriately light soufflé interspersed with some more substantial fare on the earthquake engineer's responsibilities to the public and the body politic.

Conclusion

The final event in the conference 
programme was a panel discussion poling the expertise of Professors bextero and Stein brugge, Dr. R. D. Adams, amd Messrs. O.A. Glogau, G. J. Lensen and R. I. Skinnex. under the chaimanship of Mr. R. I. Ararews. subjects discussed included the acceptability of seismic risk associated with construction neax Eault lines, a capacity design approach For structures expected to rock on their foundations, and the implications of tow parning Iegislation with respect to building hesghts.

The conference acted as an invaluable forum for designers and researchers sharing in the current statewof the-art of earthquake resistant design. Many advances have been made, but in this ineld the maxim assurediy applies that as knowledge advances so, paradoxically, does awareness of the know ledge still to be attained. one aspect of this is that research in the past has been dixected towaxds an understandino of the two-dimensional behavioux of structuxes and elements but there is ciearyy now uxgercy in establishing the performance of structures under the real situation of earthquake attack at random dixections to the principal axes. While pursuing this Ulyssean quest for knowleage earthquake engineers may take some solace from the words of another immortal of English 1iterature:

"It"s snowing stil1" said Eeyore gloomily. "So it is". "And Ereezing" "Is it?" "Yes" said Eeyore. "However" he said brightening up a 1ittle, "We haven "t had an earthquake lately".

\section{Conference Papers}

STE INBRUGGE, K. V. "Earthquake Disaster Response planning: An Engineering overview". BERTERO; $V$. $V_{*}$ " "Identification of Research Needs for Improving the Aseismic Design of Building Structures".

KoxsToN, D. "Notes on the New Zealand

Earthquake Loading Provisions"

SKINNER, R. I, and McVERRY, G. H., "Base

Isolation for Increased Earthouake Resistance of Builaings".

STEPHENSON, W. R. "Cellular Normal Modes of Alluvium Response".

ADAMS, R. D. "Developments in studies of Eaxthquake Risk".

GAULL, B., "Accelerograph Recordings at the

Musa Earthquake 16 September, $1972^{\prime \prime}$.

PARK, R. AND PAULAY, T. "Ductile Reinforced

Concrete Frames -.- Some Comments on the Special provisions for Seismic Design of ACI $318-71$ and on Capacity Design".

WILIIAMS, R. I. "A Procedure for the Analysis and Design of Ductile Reinforced Concrete Frame Buildings of Moderate Height". Poote, R. A. "Design of a 28-storey Reinforced Concxete Building in Wellington".

WOOD, J. K., "Earthquake Induced Pressures on a Rigid Wall structure".

PARK, R. and THOMPSON, K. J., "Progress Report on Cyclic Load Tests on Prestressed, Partially prestressed and Reinforced Concrete Interior Beam-Column Junctions".

BLAKELEY, R. W. G., MEGGET, I. M, and

PRIESTLEY, M. J. N. "Seismic performance of

Two Full Sized Reinforced Concrete Beamm

Column Joint Units".

CROAD, R. N. MEAD, $F$. $\mathbb{N}_{\text {. }}$ and SHEPKERD, R.,

"rhe Cycilc yield Resporse of a steel star

plate Cruciform Joint".
TORD, J., HOERNER, J. B. and ZAYED, M. "Trelastic Dymamic Aralysis of Steel Structures". SkARPE, R. D. and CARR, A. J., "The seismio Response of Inelastic Structures". PRIESTIEX, M. J. $\mathbb{N}_{\text {. }}$ and BRIDGEMAN, D. G. "Seismic Resistance of Brick Masonry Walis". LEUCHARS, J.M. and SCRIVENER, J. C., "Masonry Infili panels subjected to cyclic Iro-Plane Loading".

GLOGAU, O. A." "Separation of Non Structural Components in Builaings".

SHEPHERD, $R$. and ROSS, D. A. "Inelastio Characteristics of a Reimforced Concrete Exame

WILLIRMS, D. and GODDEN, W. G., "MuItidirectional seismic Response of a Curved Highway Bridge Model".

BLARELEY, R.W.G., COONEY, R.C. and MEGGET, L. M. "Seismic shear Loading at Flexural Capacity in Cantilever Wall Structures".

SMITH, I. C., SPRING, K. C. and STDWELI, G. K., "The Structural Design of the New Head office Building of the Bank of New Zealand, Wellington".

ROBINSON, $W$. H, and GREENBANK, $L, R$. "Properties of an Extrusion Energy Absorber".

\section{SOCIETY MANAGEMENT COMMITTEE}

The following are Members of the Society"s Management Commitee for the year $1975-76:-$

Elected:-

Dr. R. W. G. Blakeley

Mr. R* J* Bums

Mr. O. A. Glogau

* Mr. D. S. Mackenzie

Mr. L. E. oborn

Mr. I. C. smith

Nominated :-

Earthquake \& War Mr. J.L. Gill

N.Z. Inst. of

Engineers

Mr. I. P. Holings

N.z. Inst. of

Architects

Mr. S. W. Toomath

Royal society of Dr. R. D. Adams and

N.Z.

Mr. R. I. Skinner

Comopted :-

Mr. H. M. Trvine

Mr. G. H. F. McKenzie

Mr. T.N. Mitchell

* President of the society. 